\title{
CHARACTERISTICS OF THE GEOGRAPHICAL DISTRIBUTION OF DRAGONFLIES (INSECTA: ODONATA) IN THE FERGHANA VALLEY
}

\author{
Mohidilkhan Suvankhanovna Zokirova \\ Andijon State University, PO170100, University str., 129, Andijan, Uzbekistan \\ https://doi.org/10.35410/IJAEB.2020.5494
}

\begin{abstract}
The article describes the species composition of the odonatofauna of the South-East of the Ferghana valley and the distribution of species in different geographical and climatic zones. In particular, the species composition of dragonflies in three different geographical and climatic zones of the Andijon region was determined. As a result of the conducted research, it was found that 15 species of dragonflies are common in the studied territory of Eastern Fergana: Sympecma fusca Vander Linden, 1820; Lestes dryas Kirby, 1890; Calopteryx virgo Linnaeus, 1758; Calopteryx splendens Harris, 1782; Ischnura elegans Vander Linden, 1820; Anax parthenope Selys, 1839; Anax imperator Leach, 1815; Aeshna juncea Linnaeus, 1758; Aeshna isosceles Muller, 1767; Sympetrum vulgatum Linnaeus, 1758; Sympetrum meridionale Selys, 1841; Libellula depressa Linnaeus, 1758; Orthetrumcan cellatum Linnaeus, 1758; Orthetrum brunneum fonscolombe, 1837; Ophiogomphus Cecilia Fourcroy, 1785. It was found that 15 species are common in the plain zone, 13 species are common in the hill zone, and 11 species of dragonflies are common in the mountain zone.
\end{abstract}

Keywords: Dragonfly, imago, larva, territory, geographic and climatic area, species composition, odonato fauna, Ferghana.

\section{INTRODUCTION}

Dragonflies participate in the food chain of aquatic and terrestrial biogeocenoses and play an important role in the energy exchange and transformation of nutrients. Morphological, physiological, bioecological features, ethology and many other properties of dragonflies are used in biological research, as well as a model for the development of engineering structures in the field of aviation technology [1, 2]. In aquatic and terrestrial biogeocenoses, the dragonfly population is used as a bioindicator for monitoring environmental conditions as a highly sensitive species in relation to environmental factors. Although dragonflies do not have a great economic value in human economic activity, they have a certain value as exterminators of insect pests of certain agricultural crops, in addition they have an aesthetic value in the nature surrounding us $[3,4]$.

Some researchers have studied the geographical distribution of dragonfly species in climatic zones, and it was noted that the distribution of dragonfly larvae in reservoirs is related to the temperature of the environment, the amount and composition of nutrients [5]. 
There are publications that analyze the distribution of individual dragonfly species in the Central Asian region by vertical altitude climatic zones [6]. The life cycle of dragonflies is associated not only with terrestrial ecosystems but also with aquatic ones since they live in an aquatic environment at the larval stage. At present, the increase in the level of pollution of aquatic ecosystems under the influence of anthropogenic factors (pollution with industrial waste and heavy metals/pesticides, etc.) is noted as a serious threat to dragonfly populations in many regions of the world [7].

In turn, the study of the species composition, habitat, and bio-ecological features of individual dragonfly species is of great importance from the point of view of protecting endangered species [8].

Dragonflies occupy a special place in the insect class due to their phylogenetic, morphoanatomical structure and are represented by "scattered" species within ranges. A total of 172 species belonging to 52 genera have been registered in the CIS [9].

The purpose of this study was to study the species composition of dragonflies in the Andijon region of Uzbekistan and its distribution by geographical and climatic zones.

\section{MATERIALS AND METHODS}

The research was conducted in the following geographical and climatic zones of the South-East of the Ferghana valley of Uzbekistan in the period 2017-2018-2019 (spring-summer-autumn):

Plain zone - collectors in the Balykchy district of Andijon region, artificial fish ponds in Ulugnor district, collectors around the Big Ferghana channel, channels and collectors of the Boz district (height 393-511 $\mathrm{m}$ above sea level);

Hill zone- ditch and collectors in the area Ekin - Tekin Andijon district of Andijon region, the coastal basin of the Andijonsay river in Kurgantepa district; ditch and collectors Tentaksay and Chirtaksay in the village of Uchkhoz Pakhtaabad district, ditch in the vicinity of the South Fergana channel in Markhamat district, ditch in the area flowing through the territory in Asaka district of the Big Fergana channel and Shahrihansay (height 517-605 m above sea level);

Mountain zone - the upper reaches of Andijonsay in the recreation area, located in the countryside Hontoh city of Khanabad in Andijon region; the basin of the flowing through the territory of the city of Khanabad, channel Sawai, and ditch crossing the mountain Kertos in Khujaobod (height 1054-1184 m above sea level).

The main hydrographic elements of the territory are the Syr Darya, Kara Darya, Naryn rivers and related tributaries. Additional hydrographic objects of the study area serve ditch Balykchy district, Andijon district, irrigation ditches, reservoirs and ditch site Ekin - Tekin Andijon district, ditch in the vicinity of the South Fergana channel in Markhamat district, ditch in the area flowing through the territory in Asaka district of the Big Fergana channel and Shahrikhansay, fisheries. The upper course of the Andijonsay in the recreation area located in the Hontog district 
of Khanabad, Andijon region; the basin of the Kara-Darya flowing through the territory of the city of Khanabad, channel Sawai, and ditch crossing the mountain Kertos in Khujaobod, drainage of the coastal areas of Andijonsay in Kurgantepa district, Shahrihansay in Boz district, ditch and collectors Tentaksay and Chirtaksay in the village of Uchkhoz Pakhtaabad district, artificial fish ponds in Ulugnor district, and part of the Big Fergana Channel, belonging to Andijon region.

The territory of the Andijon region consists of different geographical and climatic zones, the Western and North-Western parts of which are located at an altitude of 300-500 m above sea level (steppe zone); the southern part - at an altitude of 500-1200 m above sea level hill zone), the rest (mountain zone) is located at an altitude of 1200 or more $\mathrm{m}$ above sea level (Table 1) [10].

Table 1: Classification of the study area by height of geographical and climatic zones

\begin{tabular}{|l|c|}
\hline \multicolumn{1}{|c|}{$\begin{array}{c}\text { Geographical and } \\
\text { climatic zones }\end{array}$} & Altitude above sea level (m) \\
\hline Steppe (plain) & $300-500$ \\
\hline Hill zone & $500-1200$ \\
\hline Mountains & 1200 and higher \\
\hline
\end{tabular}

In studies to determine the species composition of dragonflies (Insecta, Odonata), an expeditionroute method was used. The collection of dragonfly imagos, the identification of species, and their classification were carried out using determinants in the standard way [11].

\section{RESULTS AND DISCUSSION}

As a result of the conducted research, it was found that 15 species of dragonflies are common in the studied territory of Eastern Fergana. Table 2 shows the distribution of identified species in the studied geographical and climatic zones of the Andijon region (Table 2).

Table 2: Composition of dragonfly species distributed in some geographical and climatic zones of the Andijon region of the Republic of Uzbekistan

\begin{tabular}{|c|c|c|c|c|}
\hline \multirow[t]{2}{*}{ № } & \multirow[t]{2}{*}{ Species } & \multicolumn{3}{|c|}{$\begin{array}{c}\text { Distribution by geographical and climatic } \\
\text { regions }\end{array}$} \\
\hline & & I & II & III \\
\hline 1 & Sympecma fusca Vander Linden, 1820 & + & & \\
\hline 2 & Lestes dryas Kirby 1890 & + & & \\
\hline 3 & Calopteryx virgo Linnaeus, 1758 & + & + & \\
\hline 4 & Calopteryx splendens Harris, 1782 & + & + & \\
\hline 5 & Ischnura elegans Vander Linden, 1820 & + & + & + \\
\hline 6 & Anax parthenope Selys, 1839 & + & + & + \\
\hline 7 & Anax imperator Leach, 1815 & + & + & + \\
\hline
\end{tabular}


Vol. 5, No. 02; 2020

ISSN: $2456-8643$

\begin{tabular}{|l|l|c|c|c|}
\hline 8 & Aeshna isosceles Muller, 1767 & + & + & + \\
\hline 9 & Aeshna juncea Linnaeus, 1758 & + & + & + \\
\hline 10 & Sympetrum vulgatum Linnaeus, 1758 & + & + & + \\
\hline 11 & Sympetrum meridionale Selys, 1841 & + & + & + \\
\hline 12 & Orthetrum cancellatum Linnaeus, 1758 & + & + & + \\
\hline 13 & $\begin{array}{l}\text { Orthetrum brunneum Fonscolombe, } \\
1837\end{array}$ & + & + & + \\
\hline 14 & Libellula depressa Linnaeus, 1758 & + & + & + \\
\hline 15 & Ophiogomphus cecilia Fourcroy, 1785 & + & + & + \\
\hline
\end{tabular}

Note: I - Plain zone II -Hill zone; III - Mountain zone

Plain zone: studies have found that in the ditch of the Balykchy district of the Andijon region, widespread Calopteryx splendens, Sympecma fusca, Lestes dryas, Anax parthenope,

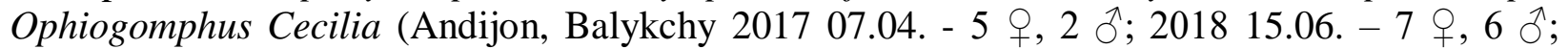
2019 29.03. - 5 +, 7 o.), in the area of artificial fish ponds in Ulugnor - Orthetrumcan cellatum, Orthetrum brunneum, Libellula depress, Anax imperator, (Andijon, Ulugnor 2017 12.06. - 6 +,

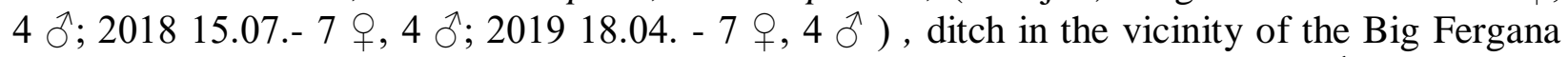

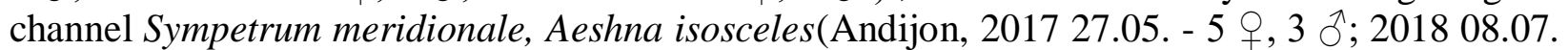
-- 5, $7 \mathrm{O} ;$;) , in channels and reservoirs Boz district found the larvae of species Calopteryx splendens, Sympetrum vulgatum, Aeshna juncea and Calopteryx virgo (Andijon, Boz 2018 09.04.

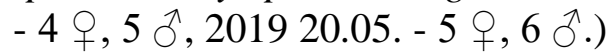

Hill zone: in the zone of channels and water intake sections of the southern Ferghana channel in the Markhamat district Calopteryx virgo, Calopteryx splendens, Ischnura elegans, Anax parthenope (Andijon, Markhamat 2017 12.09. - 1 q, 2 ○; 2018 10.05. - 4 q ; 2019 25.07. - 3 ㅇ, $2 \lambda$. ), in the vicinity of the Large Ferghana channel that flows through the territory of the a Asaka district and Shakhrikhansay, there are species of dragonflies Ischnura elegans, Calopteryx splendens, Calopteryx virgo, Anax imperator, Orthetrum brunneum, Orthetrum cancellatum, Anax parthenope, (Andijon, Asaka 2017 15.10. - 2 †, 3 ô; 2018 06.06. - 3 ค, 2 ภ. , 2018 18.05. - 4 9, 3 O; ). Imagos of the species, Ischnura elegans and Libellula depressa

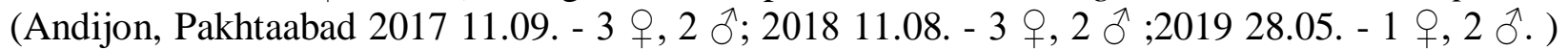
were found in the water intakes of the Kara Darya located in the territory of Pakhtaabad district. Larvae of Ophiogomphus cecilia and Sympetrum meridionale species have been found in catchment areas near the Kara Darya coast in the Pakhtaabad district (Andijon, Pakhtaabad 2017

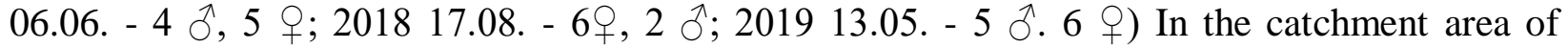
stations and ditch location Ekin-Tekin Andijon district, near the banks of the Andijonsay Aeshna juncea, Aeshna isosceles, Sympetrum vulgatum, Ophiogomphus cecilia (Andijon, Ekin - Tekin

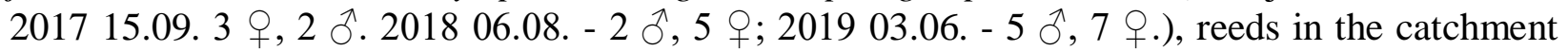
areas Kurgantepa district of Andijon region (Phragmites australis) found adults of the species Calopteryx virgo, Calopteryx splendens, Aeshna isosceles, Sympetrum meridionale, Libellula depressa, Orthetrumcan cellatum and Orthetrum brunneum (Andijon, Kurgantepa 2017 22.04. -

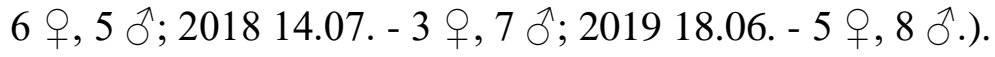


Vol. 5, No. 02; 2020

ISSN: $2456-8643$

Mountain zone: the upper course of the Andijonsay in the recreation area located in the Hontog district of Khanabad, Andijon region; Aeshna juncea, Orthetrumcan cellatum, Orthetrum brunneum, and Sympetrum vulgatum species (Andijon, Khanabad 06.09.2017- 4 \%, 7

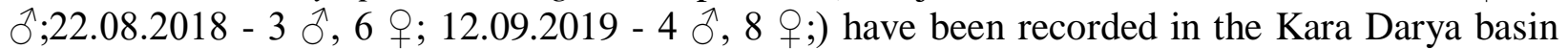
that flows through the city of Khanabad, in the Sawai channel and ditch crossing mount Kirtosh in the Khojaabad district Anax imperatori, Anax parthenopi, Sympetrum meridionale, Aeshna Isosceles, Ischnura elegans and Ophiogomphus cecilia (Andijon, Khanabad 2017 10.07. - 6 +, 7

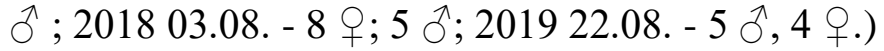

\section{CONCLUSIONS}

During 2017-2019 (spring-summer-autumn), the species composition and odonatofauna, as well as the distribution of individual species in different geographical and climatic zones of the SouthEast of the Ferghana valley of Uzbekistan were studied. As a result of the conducted research, it was found that 15 species of dragonflies are common in the surveyed territory. Cured species Sympecma fusca Vander Linden, 1820; Lestes dryas Kirby, 1890; Calopteryx virgo Linnaeus, 1758; Calopteryx splendens Harris, 1782; Ischnura elegans Vander Linden, 1820; Anax parthenope Selys, 1839; Anax imperator Leach, 1815; Aeshna juncea Linnaeus, 1758; Aeshna isosceles Muller, 1767; Sympetrum vulgatum Linnaeus, 1758; Sympetrum meridionale Selys, 1841; Libellula depressa Linnaeus, 1758; Orthetrumcan cellatum Linnaeus, 1758; Orthetrum brunneum Fonscolombe, 1837; Ophiogomphus cecilia Fourcroy, 1785. The species composition of dragonflies in three geographical and climatic zones of the Andijon region was established. There are 15 species in the plain zone, 13 species in the hill zone, and 11 species of dragonflies in the mountains.

\section{REFERENCES}

[1] Belyshev B. F., Kharitonov A. Yu., Kharitonova I. N., Borisov S. N. Composition of the dragonfly fauna of the USSR. Fauna and ecology of dragonflies. Novosibirsk. Publishing house: Nauka (Sib. ed.), P.207, 1989. (In Russian).

[2] Dronzikova M.V. Dragonfly the basin of the Tom river: Composition and distribution of the fauna, ecological and ethological features of the species. Abstract of diss. ... cand. boil. scien., (03.00.09-entomology). Novosibirsk, P. 19, 2000. (In Russian).

[3] Tikhonov A.V. Ecological-biological peculiarities of dragonflies and odontogenic highaltitude zones of the Central Caucasus. Abstract of diss. cand. biol. scien., Nalchik, P. 20, 2012. (In Russian).

[4] May M.L. Odonata: Who they are and what they have donefor us lately: Classification and ecosystem services of dragonflies. Insects. V.10 (62), pp, 1-17, 2019. (In English)

[5] Zalikhanov K.H. The Fauna and ecology of dragonflies of the Central Caucasus. Abstract of diss. cand. biol. scien., (03.00.08-Zoology), Makhachkala, P. 18, 2005. (In Russian).

[6] Chaplina I.A. Fauna and ecology of dragonflies of Kazakhstan. Abstract of diss. cand. biol. scien., Novosibirsk, P. 20, 2004. (In Russian).

[7] Kalkman V.J., Boudot J.P., Bernard R., Conze K.J., De Knijf G., Dyatlova E., Ferreira S., Jovic M., Ott J., Riservato E., Sahlen G. European Red List of Dragonflies. Luxembourg: Publications Office of the European Union. P. 38, 2010. (In English). 
[8] Daguet C., French G., Taylor P. The Odonata Red Data List for Great Britain. Species Status (Eds.). Joint Nature Conservation Committee (Peterborough), P. 34, 2007. (In English).

[9] Borisov S. N., Kharitonov A. Yu. Dragonflies (Odonata) Of Central Asia. Part 2 (Anisoptera) / / Eurasian entomological journal .-2008. - No. 7. - Pp. 97-123.

[10] Baratov P. Natural geography of Uzbekistan. Tashkent, Ukituvchi, P. 264, 1996. (In Uzbek).

[11] Keller T.S., Stearns A.M., Krieger K.A. Atlas of the Dragonfly Larvae (Class Insecta: Order Odonata: Suborder Anisoptera) recorded at the old woman Creek National estuarine research reserveand state nature preserve. National center for Water Quality Research Heidelberg College Tiffin (Ohio, USA). 2007. 